\title{
PROSES PERANCANGAN STRATEGI PROMOSI: Studi Kasus pada Sebuah Start-up Business
}

\author{
Oleh: \\ Cindy Amelia ${ }^{1)}$ Wirawan ED Radianto ${ }^{2)}$ \\ Universitas Ciputra Surabaya \\ email $^{2}$ : wirawan@ciputra.ac.id
}

\begin{abstract}
Abstrak
The purpose of this study is to formulate promotion strategy for start-up business. In order to get comprehensive and deeper understanding this study uses qualitative approach. There are three categories of informant namely competitors, consumers, and expert. In depth interview and observation are used in collecting important data. Validity come from triangulation technique and data is analyzed by Miles and Huberman method. This study shows that there are five strategies for promotion namely social media, photography, discount, endorse, and website. Finally, attending exhibition is very important for this business in order to get many customers.
\end{abstract}

Key words:promotion, strategy, start-up business, social media

\section{PENDAHULUAN}

Strategi promosi memegang peranan yang penting dalam persaingan bisnis yang sangat kompleks saat ini. Melalui strategi promosi yang tepat dan efektif maka dapat menarik minat target konsumen. Menurut Tjiptono (2012) promosi merupakan segala bentuk penawaran atau insentif jangka pendek yang ditujukkan bagi pembeli, pengecer, atau pedagang grosir dan dirancang untuk memperoleh respon spesifik dan segera. Promosi juga diartikan sebagai komunikasi yang membangun dan menjaga hubungan dengan cara memberi informasi dan memersuasi masyarakat untuk melihat suatu organisasi secara positif dan menerima produknya (Hult et al., 2012).

Dari uraian tersebut strategi promosi tidak hanya harus dimiliki oleh bisnis yang sudah berjalan dalam skala besar, namun juga bisnis dalam skala kecil bahkan mikro. Penelitian ini menginvestigasi strategi promosi yang dilakukan oleh bisnis yang sedang dirintis (Start-up Business) yang bernama RawrClothing. Start-up business 
dipilih dalam penelitian ini karena masih sangat sedikit penelitian mengenai strategi promosi di perusahaan yang masih dalam proses perintisan. Penelitian ini sangat bermanfaat karena temuan dalam penelitian ini dapat digunakan sebagai alternatif strategi bagi usaha yang sedang dirintis terutama usaha bisnis yang bergerak secara daring. Lebih lanjut dipilihnya bisnis daring tidak lepas dari perkembangan bisnis internet di Indonesia yang meningkat tajam.

Strategi pemasaran yang telah dilakukan selama ini oleh RawrClothing melalui berbagai cara misalnya mengikuti pameran, menggunakan sosial media seperti instagram, facebook, twitter, dan mengiklankan produk melalui situs jual beli daring, seperti olx, kaskus, dan lain-lain. Namun demikian respon yang didapat kurang baik, hal ini dapat dilihat dari penjualan yang rendah. Dalam upayanya untuk meningkatkan penjualan maka RawrClothing tidak hanya melakukan penjualan langsung, namun juga menjual produk dengan cara konsinyasi ke butik-butik. Di samping itu, RawClothing mencari desain baru untuk membuat produk baru, sehingga bisa memberikan pilihan lebih banyak kepada konsumen dengan tujuan untuk menaikkan penjualannya. Namun demikian penjualan juga tetap tidak meningkat. Setelah pemilik melakukan investigasi mulai dari pasokan bahan baku sampai dengan proses produksi ditemukan bahwa semua proses dapat berjalan dengan baik, namun pada saat produk tersebut dijual hasilnya tidak sesuai dengan yang diharapkan. Pemilik kemudian merencanakan untuk merancang kembali strategi promosi dalam rangka mendapatkan pasar sasaran yang tepat. Strategi promosi yang dirancang adalah strategi promosi daring, karena melalui promosi daring akan mampu memperoleh pangsa pasar yang lebih luas.

Beberapa penelitian yang telah dilakukan berhasil membuktikan bahwa sistem penjualan secara daring bisa dijadikan sarana transaksi alternatif dan bisa digunakan untuk promosi (Listyorini, 2013). Paramita, et al. (2014) meneliti bagaimana etno fashion Sieto menggunakan strategi promosi yang tepat dan efektif 
mampu menarik minat konsumen yang ditargetkan. Penelitian ini menemukan bahwa promosi sangat berpengaruh karena dengan promosi yang tepat dan efektif bisa menjangkau pasar dan merek yang ditawarkan bisa dikenal masyarakat, selain itu promosi bisa meningkatkan penjualan dan memperluas jangkauan konsumen. Nazir, et al. (2012) menemukan bahwa sebagian besar orang sudah melakukan pembelian daring dan lebih memilih untuk belanja daring. Tetapi ada beberapa faktor yang memengaruhi sikap konsumen dalam melakukan pembelian daring. Faktor-faktor tersebut antara lain faktor psikologis, sosial, emosional, dan privasi. Faktor yang terpenting bagi konsumen dalam melakukan pembelian daring adalah harga, kepercayaan, keamanan, dan rekomendasi. Beberapa penelitian tersebut meneliti bagaimana strategi promosi daring mampu untuk meningkatkan penjualan. Namun demikian penelitian-penelitian tersebut tidak menginvestigasi bagaimana proses strategi promosi daring mulai dari perumusannya sampai kepada mengapa strategi tersebut dipilih untuk diterapkan.

Penelitian ini mengekplorasi perancangan strategi promosi RawrClothing untuk meningkatkan penjualan. Penelitian ini memberikan kontribusi mengenai proses perancangan strategi promosi daring yang belum pernah dilakukan oleh peneliti-peneliti sebelumnya. Oleh karena itu tujuan penelitian ini adalah untuk menjelaskan bagaimana proses perancangan strategi promosi RawrClothing. Perbedaan lainnya dengan penelitian sebelumnya adalah penelitian ini mengambil kasus startup business yaitu perusahaan yang sedang merintis bisnisnya, sehingga penelitian ini memberikan kontribusi pada pengembangan usaha kecil dan menengah terutama dalam aspek strategi promosi daring. Penelitian ini juga melibatkan informan berasal dari pesaing, konsumen, dan pendapat para ahli yang belum pernah dilakukan penelitianpenelitian sebelumnya.

Dalam upaya untuk menggali lebih dalam mengenai proses strategi promosi, maka penelitian ini menggunakan pendekatan kualitatif. Penelitian ini tidak berdasarkan pada 
teori tertentu seperti layaknya penelitian dengan pendekatan kuantitatif. Hasil penelitian ini menemukan bagaimana strategi promosi yang dilakukan oleh start-up business.

\section{Metode Penelitian}

Penelitian ini bertujuan untuk merancang strategi promosi RawrClothing berdasarkan analisis strategi promosi yang diterapkan oleh para pesaing, pendapat konsumen, dan pendapat para ahli. Untuk mampu menggali hasil yang mendalam maka peneliti menggunakan pendekatan penelitian kualitatif. Pendekatan penelitian kualitatif ini dipilih oleh peneliti karena topik penelitian perlu dieksplorasi, tidak tersedianya teori untuk menjelaskan perilaku partisipan dalam proses perancangan strategi promosi daring, dan peneliti perlu menyajikan pandangan detail tentang topik (Creswell, 1998 dalam Emzir, 2010). Penelitian ini berusaha mengungkap jawaban mengenai "bagaimana" proses yang dilakukan dalam penelitian, sehingga penelitian ini menggunakan strategi metode studi kasus tunggal. Melalui strategi ini maka akan didapatkan data yang mendalam dan hasil yang lebih komprehensif (Yin, 2003). Penelitian kualitatif deskriptif digunakan dalam ekplorasi terhadap subyek penelitian melalui pengamatan, wawancara, dan dokumentasi dideskripsikan dalam catatan kualitatif (Putra, 2012).

Penelitian ini menggunakan teknik snowball sampling, karena jumlah sampel yang digunakan peneliti ditentukan selama pengambilan sampel, hingga mencapai data jenuh (Sugiyono, 2012). Dalam menentukan informan agar diperoleh informan yang mumpuni, maka beberapa kriteria informan adalah sebagai berikut. Informan pesaing yang digunakan adalah pesaing yang memiliki beberapa kriteria seperti memiliki pengikut pada instagram lebih dari 10.000 account, melakukan launching produk setiap kurang dari enam bulan, membuat produknya sendiri (self manufactured), dan mendapat lolohbalik positif dari konsumen leih dari 50 konsumen.

Kriteria yang digunakan dalam memilih konsumen adalah konsumen tersebut melakukan pembelian produk fesyen dalam tiga bulan 
terakhir, mengenal produk-produk fesyen dalam negeri, dan sering melakukan pembelian daring. Kriteria para ahli yang digunakan adalah yang bersangkutan merupakan ahli pemasaran yang terdiri dari dosen dan konsultan pemasaran. Penelitian ini menggunakan tiga nara sumber yang berbeda karena ingin mengintegrasikan pendapat dan pengalaman dari ketiga sumber yang kompeten tersebut.

Metode yang peneliti gunakan untuk mengumpulkan data dari konsumen dan para ahli menggunakan wawancara, sedangkan untuk pesaing menggunakan wawancara dan observasi. Wawancara yang dilakukan dengan menggunakan wawancara semi terstruktur, sehingga data yang didapat lebih mendalam namun masih fokus dengan tujuan. Perolehan data ini dilakukan dengan dua cara, yaitu wawancara melalui chatting dan bertatap muka. Wawancara dilakukan untuk memperoleh data berupa strategi promosi yang digunakan pesaing untuk memperkenalkan produknya dan memperoleh pembeli, juga untuk mengetahui secara rinci keinginan konsumen, dan memahami pendapat para ahli. Observasi dilakukan dengan cara melihat media sosial pesaing, dengan mencermati jumlah pengikut instagram dan loloh-balik yang didapatkan oleh pesaing. Lolong-balik yang didapatkan bisa dilihat dari post konsumen pesaing dan dari repost yang pesaing unduh pada media sosialnya. Observasi adalah untuk mengetahui data kinerja pesaing, sehingga peneliti bisa mengetahui pesaing mana yang lebih sukses dan bisa dijadikan narasumber untuk wawancara.

Selanjutnya, untuk mendapatkan data yang sahih, maka penelitian ini menggunakan triangulasi. Triangulasi merupakan pengecekan data dari berbagai sumber dengan berbagai cara dan waktu (Sugiyono, 2012). Triangulasi yang digunakan pada penelitian ini adalah triangulasi sumber. Setelah data diperoleh maka langkah selanjutnya adalah analisis data. Analisis data yang digunakan adalah analisis data menurut Miles dan Huberman. Metode analisis data ini berisi tiga tahapan dalam menganalisis data, yaitu reduksi data, 
penyajian data, dan penarikan simpulan (Ghony \& Almanshur, 2012).

Metode analisis data ini dipilih dengan alasan metode ini memiliki alur yang sistematis dan runtut, sehingga peneliti bisa menganalisis data berurutan sesuai dengan alur metode Miles dan Huberman.

\section{HASIL PENELITIAN}

RawrClothing adalah usaha yang bergerak dalam bidang fesyen yang menjual berbagai macam pakaian wanita. Awalnya RawrClothing menjual tas, skirt, crop tee, dan kaos, Namun saat ini RawrClothing hanya fokus menjual kaos yang diproduksi sendiri. Produk yang RawrClothing jual adalah kaos dengan desain tulisan yang diproduksi sendiri. Sebelum berbisnis di produk tersebut usaha ini menjual skirt, crop top, dan tas yang dibeli dari supplier. Saat ini RawrClothing ingin mengembangkan bisnis lagi ke arah pakaian yang memiliki tema khusus setiap sesinya atau tematik, karena berdasar hasil observasi yang peneliti lakukan, saat ini masyarakat Indonesia sudah lebih sadar bahwa produk dalam negeri tidak kalah bagusnya dengan produk luar negeri, ditambah lagi produk dalam negeri memiliki harga yang lebih terjangkau.

Proses pengumpulan data dimulai dengan proses pencarian informan baik yang menjadi pesaing, ahli, dan konsumen. Selanjutnya peneliti mengadakan janji untuk bertemu. Proses mencari waktu yang tepat merupakan hal yang sangat sulit dilakukan di proses penelitian ini. Setelah waktu yang ditentukan dapat disepakati maka peneliti mengadakan wawancara yang sekaligus direkam peneliti. Selanjutnya proses observasi dilakukan oleh peneliti untuk menguatkan data yang telah dikumpulkan. Layaknya penelitian dengan pendekatan kualitatif, maka proses analisis data dimulai bersamaan dengan proses pengambilan data. Oleh karena itu proses tersebut dilakukan secara hatihati untuk memastikan bahwa data diperoleh adalah sahih dan peneliti melakukan proses untuk memastikan data adalah sahih dengan cara lebih lama berada di aktivitas informan. Berikut ini disajikan proses wawancara yang dilakukan peneliti.

Peneliti melakukan wawancara ke sejumlah pesaing, berikut adalah 
beberapa hasil wancara yang telah dilakukan. Rouse merupakan pesaing yang memproduksi sendiri produknya. Dalam melakukan promosinya Informan-1 hanya melalui instagram dengan cara endorse dan juga mengikuti pameran, seperti yang diungkapkannya sebagai berikut:

“...pameran ngaruh

banget terhadap

penjualan karena

banyak orang yang

belum mengenal Rouse

bisa mulai mengenal

produk Rouse..."

Cara promosi melalui endorsement dipilih oleh Rouse karena alasan yang diungkapkan Informan-1 sebagai berikut:

“.. karena lebih
langsung dan lebih
nyambung ke anak
muda, karena semua
anak muda sekarang
main instagram...”

Endorse yang dilakukan menggunakan artis dan blogger, karena artis dan blogger memiliki banyak para pengikut sehingga dampaknya sangat besar, seperti dalam satu sampai tiga hari produknya habis. Para pengikut pada instagram Rouse bertambah dengan pesat hingga pernah mencapai 500 para pengikut dalam satu hari, dan endorser yang paling berpengaruh adalah Anastasia Siantar, karena meskipun produk habis masih banyak dicari orang. Cara promosi tersebut untuk saat ini akan digunakan terus, karena paling berdampak dan Informan-1 belum berencana untuk menambah cara promosi lain. Target konsumen Rouse adalah fashionista yang berumur 17-30++ tahun, karena jika konsumennya fashionista produknya lebih cepat terkenal dan Informan-1 lebih suka pakaiannya dipakai oleh fashionista, karena pasti bagus secara menyeluruh.

Observasi yang dilakukan peneliti terhadap Informan-1 menunjukkan para pengikut pada instagram Rouse mencapai 10.000 user, Rouse juga mengeluarkan produk setiap periode tertentu dan setiap produknya tematik, jadi baju satu dan lain ada kemiripan. Lolohbalik yang didapatkan Rouse juga cukup banyak, sudah lebih dari 50 
loloh-balik yang masuk di instagram.

Promosi Rouse dengan cara endorse artis dan blogger seperti yang dipaparkan Devina saat wawancara, dan re-post foto konsumen yang pernah beli.

Selanjutnya peneliti mewawancarai Informan-2 yang merupakan pemilik dari La Fleur Sign. La Fleur Sign atau yang lebih dikenal La Fleur memiliki produk yang juga dijual dari desain sendiri oleh pemiliknya. Awal La Fleur membuat bisnis ini karena pemilik memiliki kesenangan di bidang fesyen sehingga pemilik suka membuat baju sendiri, dikarenakan postur tubuh informan tinggi, seperti yang diungkapkannya sebagai berikut:

“...it's hard to find my size, aku tinggi. Jadi lebih suka bikin baju sendiri....". (Informan-

2)

Selain itu, pada saat informan-2 pergi dengan menggunakan baju rancangannya ternyata banyak orang yang bertanya dan mulai pesan baju pada informan-2, sehingga muncul ide untuk membuat lini busana.
Setiap tiga bulan La Fleur selalu membuat produk baru dengan tema yang berbeda sehingga konsumen La Fleur tidak bosan dan bisa melakukan pesan ulang. Cara promosi La Fleur mirip dengan Rouse, menggunakan instagram, endorse dan website. Rencana kedepan La Fleur tetap menggunakan instagram dan situs jaringan, karena melalui dua media tersebut penjualan yang didapat sudah tinggi, namun Informan-2 juga ingin memiliki penjualan yang global, seperti ungkapnya sebagai berikut:

“...pengen sih bisa worldwide shipnya, tapi masih dreaming aja. $\mathrm{Aku}$ better doing something start from what $i$ have aja". (Informan-2)

Alat promosi yang digunakan La Fleur hanya melalui instagram dan webiste, Informan-2 menggunakan instagram karena tidak memiliki media sosial lain dan hanya aktif di instagram. Konsumen sasaran La Fleur adalah menengah ke atas, karena bahan baku dan biaya-biaya yang dikeluarkan cukup tinggi, 
sehingga harga pokok produknya sudah tinggi seperti ungkapannya:

"Soalnya aku biasa beli

kain pas ke Singapura, jadi kan ga mungkin murah, terus penjahitku biasa jahit bridal. Jadi ongkosnya uda tinggi dan bahannya juga mahal" (Informan-2).

Hasil observasi terhadap Informan-2 adalah La Fleur Sign memiliki para pengikut instagram mencapai 10.000 user. La Fleur melakukan peluncuran produk baru setiap tiga bulan dan produknya selalu memiliki keunikan, terutama pada pola kain yang tidak dimiliki lini busaya lain. Loloh-balik yang didapat dari konsumen sangat banyak, dari instagram La Fleur telah mendapat lebih dari 100 lolohbalik. Promosi yang dilakukan La Fleur dengan cara endorse ke blogger, re-post foto konsumen, unggah foto baur dan padan produk La Fleur, dan unggah foto yang menggunakan model yang menarik.

Wawancara berikutnya adalah wawancara dengan informan-3 yaitu pemilik Poise24. Informan-3 membuat bisnis ini karena menyukai dunia fesyen dan melihat adanya peluang bisnis dalam bidang fesyen. Peluang tersebut dilihat melalui banyaknya merek luar negeri yang membayar Informan-3 untuk mengiklankan produknya, karena Informan-3 adalah seorang fashion blogger. Berdasarkan hal tersebut Informan-3 membuka merek sendiri karena sudah memiliki pelanggan prospek. Produk yang dijual di Poise24 semuanya di disain sendiri olehnya, meskipun tidak memiliki desain dasar, Informan-3 mengetahui perkembangan model dan material yang diperlukan. Informan-3 hanya menjelaskan desain yang diinginkan dan ada orang yang menggambarkan, seperti yang diungkapkan:

"Saya sekolahnya
bukan fashion design,
tapi saya suka fashion,
jadi saya familiar
dengan shape, material
dan fashion trend. Jadi
saya ada orang yang
menggambar dan
membuat sampel untuk
saya dengan cara saya
ngomong jadi
digambarin langsung di


depan saya, jadi saya

maunya gimana dan dia

wujudin-nya gimana

harus cocok."

Promosi yang dilakukan menggunakan media daring, seperti ungkapnya:

“...karena bisnis saya pertamanya daring, jadi saya memilih promosi dengan daring media dan social media." (Informan-3)

Cara promosi yang dilakukan melalui media sosial, media daring, endorse, dan kolaborasi. Semua dilakukan secara daring karena awalnya sudah menggunakan strategi daring sehingga bisa melakukan post a link dan semuanya bisa dilakukan dengan hanya satu klik. Selain itu biaya lebih murah dibandingkan iklan lain, serta dengan daring lebih cepat sampai ke konsumen. Dampak promosi tersebut positif, karena penjualan terus meningkat. Strategi promosi tersebut akan digunakan terus, selain itu ada rencana ke depan untuk bekerjasama dengan editor dan stylist, serta menggunakan media promosi televisi. Media yang paling berdampak adalah instagram, karena konsumen sasaran Poise24 banyak yang menggunakan instagram, dan pengguna instagram selalu mengikuti perkembangan Poise24. Alat promosi yang digunakan oleh Poise24 adalah blog, instagram, dan website, sehingga alat yang digunakan semuanya berbasis daring. Konsumen sasaran Poise24 adalah wanita usia 18-25 tahun, kalangan menengah ke atas.

Pengikut pada instagram Poise24 mencapai 19.000 pengguna, dan loloh-balik yang didapat lebih dari 200. Berdasarkan observasi yang dilakukan, peneliti melihat bahwa Poise24 pernah diliput majalah dan pernah berkolaborasi dengan produk lain, seperti Sonny Angel, Beauphoria, dan Laduree. Selain itu Poise24 juga memberikan promo kepada pembeli yang melakukan pembelian melalui situs jaringan, dengan mengumpulkan poin. Setiap pembelian 10.000 rupiah mendapat satu poin dan berlaku kelipatan, setelah poin terkumpul sebanyak 250 mendapatkan potongan harga $10 \%$. Poise24 juga melakukan endorse ke 
beberapa blogger dan artis, re-post foto konsumen, serta memanfaatkan ketenaran keluarganya untuk promosi.

Peneliti mengkaji pesaingpesaing tersebut dan menemukan bahwa para pesaing menggunakan strategi pemasaran yang serupa, yaitu menggunakan instagram dan cara endorse untuk memperkenalkan produknya, sedangkan untuk Poise 24, dan La fleur menggunakan media lain, yaitu situs jaringan untuk pemasaran dan pembelian produknya. Kedua, tiga pesaing tersebut merupakan lini busana yang melakukan pemasaran dan penjualan dengan cara daring. Namun hasil penjualan yang para pesaing dapat cukup tinggi. Hal ini dapat dilihat berdasarkan omset dan banyaknya konsumen yang memakai produk pesaing. Berdasarkan observasi yang dilakukan peneliti, dapat disimpulkan bahwa ketiga pesaing sudah cukup sukses dalam bidang fesyen daring. Lalu, ketiga pesaing tidak pernah mempromosikan mereknya melalui media cetak, semua melalui media daring. Serta promosi yang dilakukan oleh ketiga pesaing tersebut sama, yaitu melalui instagram dengan endorse artis dan blogger.

Wawancara juga dilakukan kepada konsumen yang mengerti dunia fesyen, yang pertama wawancara kepada Informan-4. Menurutnya media promosi yang lebih cepat diterima calon pembeli adalah melalui media sosial seperti yang diungkapkan Informan-4:

$$
\begin{aligned}
& \text { "Menurut saya social } \\
& \text { media, karena kita } \\
& \text { pasti tiap hari melihat } \\
& \text { social } r \text { media, } \\
& \text { contohnya instagram } \\
& \text { dan twitter, namun } \\
& \text { yang paling efektif } \\
& \text { instagram, karena } \\
& \text { orang-orang } \\
& \text { kebanyakan punya dan } \\
& \text { sering update di } \\
& \text { instagram." }
\end{aligned}
$$

Alat promosi yang paling disukainya adalah media daring, alasannya yaitu karena lebih mudah aksesnya dan tanpa biaya. Biasanya Informan-4 lebih tertarik dengan promosi melalui foto di instagram, seperti diungkapkannya sebagai berikut:

$$
\begin{array}{lr}
\text { “....seperti modelnya } \\
\text { banyak dan }
\end{array}
$$


menggunakan

fotografer yang bagus

menurut saya sudah

menarik." (Informan-4)

Selain itu Informan-4 juga lebih menyukai promosi menggunakan diskon dibandingkan cara promosi lainnya, sedangkan cara promosi yang tidak disukai adalah promosi melalui spam di instagram, karena mengganggu. Selanjutnya Informan5 menyatakan bahwa media promosi yang lebih cepat diterima calon pembeli adalah instagram, brosur, dan broadcast message di blackberry messager. Alasannya diungkapkan Informan-5 sebagai berikut:

“...karena biasanya targetnya kan remaja, sekarang di remaja lagi booming instagram, kalau bagi brosur kan bisa ke kampuskampus, dan untuk broadcast message kan bisa langsung diterima oleh calon konsumen.'

(Informan-5)

Alat promosi yang paling disukai Informan-5 adalah instagram, karena sedang booming sehingga bisa menjangkau banyak calon konsumen. Promosi yang menarik minat beli Informan-5 adalah promosi dengan diskon, sedangkan yang tidak disukai adalah spam di instagram, dengan alasan sebagai berikut:

$$
\begin{aligned}
& \text { “...karena mengganggu } \\
& \text { pengguna instagram, } \\
& \text { sehingga pada saat ada } \\
& \text { teman yang comment } \\
& \text { jadi tertumpuk oleh } \\
& \text { spam tersebut dan notif } \\
& \text { yang masuk juga } \\
& \text { mengganggu." }
\end{aligned}
$$

Informan-6 menyatakan bahwa media promosi yang lebih cepat diterima calon pembeli adalah media sosial, seperti instagram, facebook, dan website, karena media sosial tersebut adalah yang paling banyak diminati masyarakat menurutnya. Alat promosi yang paling disukainya adalah media daring, seperti ungkapnya:

$$
\begin{aligned}
& \text { "seperti ig (instagram) } \\
& \text { dan blog, karena lebih } \\
& \text { praktis dan kita } \\
& \text { jamannya gadget-an } \\
& \text { jadi jika melalui media } \\
& \text { sosial kan bisa diakses } \\
& \text { dari } \\
& \text { mana-mana }
\end{aligned}
$$


sehingga kita bisa tahu

promosinya.".

Promosi yang bisa menarik minat Informan-6 untuk membeli produk adalah diskon dan foto produk tersebut, karena semua orang menyukai diskon menurut Angel, dan karena sekarang banyak gerai daring sehingga tidak bisa melihat barang langsung. Sehingga foto yang menarik sangat penting. Alat promosi yang tidak disukai adalah spam di surel, karena mengganggu aktivitas di surel pengguna.

Berdasarkan ketiga konsumen yang telah diwawancarai, para konsumen menganggap media sosial merupakan media yang lebih cepat diterima calon konsumen, terutama instagram. Alat promosi yang disukai para konsumen adalah media daring, dan promosi yang menarik minat beli konsumen adalah diskon dan foto yang menarik. Promosi yang para konsumen tidak sukai adalah spam, baik pada instagram maupun surel.

Wawancara terakhir peneliti lakukan kepada para ahli pemasaran. Menurut Informan-7, strategi promosi yang tepat digunakan pada bisnis fesyen adalah mengikuti pameran dan menggunakan daring shop, namun gerai daring tidak hanya yang lokal, tapi juga memasuki pasar internasional. Pameran menjadi strategi yang tepat untuk bisnis baru, sehingga melalui pameran bisa memperkenalkan merek, seperti yang diungkapkan Informan-7 sebagai berikut:

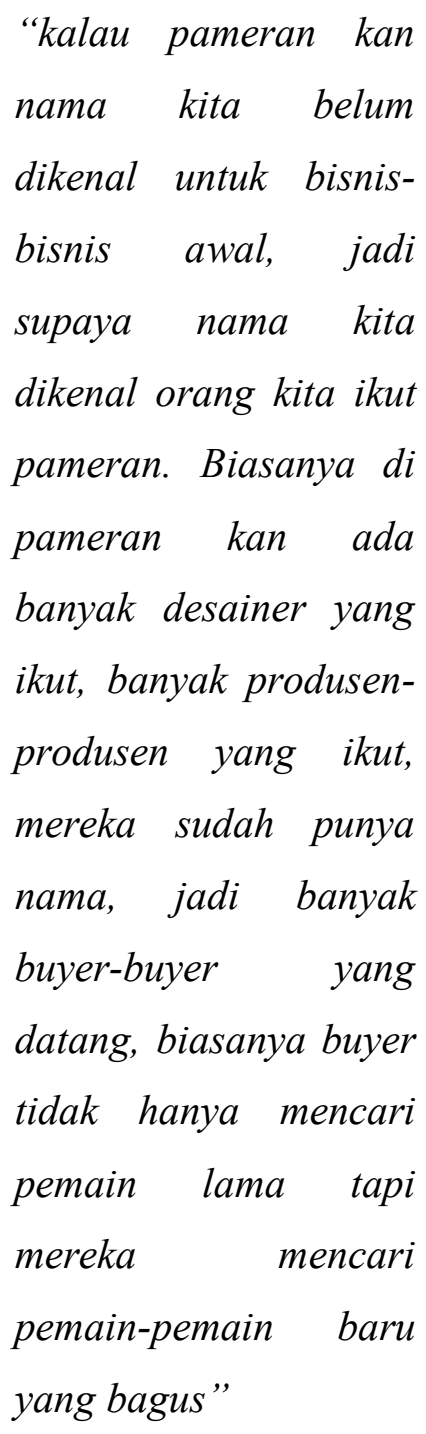


Alasan menggunakan gerai daring karena langsung dapat dijual ke pemakai, dan bisa mencapai perdagangan internasional yang tidak hanya menargetkan pengguna akhir tetapi bisa juga ke B2B. Alat promosi melalui daring untuk menargetkan konsumen lokal yang paling efektif adalah indonetwork untuk B2B dan instagram untuk pengguna akhir. Hal yang perlu diperhatikan dalam promosi adalah pengetahuan produk, terutama dalam fesyen harus tahu tren di pasar. Cara promosi yang paling efektif untuk memasarkan produk adalah promosi yang tidak banyak kata-kata, tetapi hanya menggunakan kata yang sangat menarik dan menggunakan gambar yang menarik, karena jaman sekarang orang ingin yang praktis, jika promosi terlalu banyak kata-kata membuat orang kurang percaya.

Informan-8 mengungkapkan strategi promosi adalah sebagai berikut.

"Strategi promosi itu suatu tools atau cara yang digunakan perusahaan, tujuannya pasti macam-macam, ada yang sampai merek-nya cuma cukup

dikenal atau sampai

orang melakukan

pembelian, jadi kalau

bisa sampai nge-push

orang itu berarti

tahapan paling akhir

dari strategi promosi”.

Strategi promosi yang tepat untuk bisnis fesyen adalah strategi yang mendorong orang membeli dengan pelan-pelan, seperti melakukan pameran, pemberian diskon atau promosi penjualan lainnya, serta pemberian jasa konsultasi. Sedangkan untuk mereknya bisa membangun citra mereknya dari kemasan dan tampilan. Strategi tersebut dipilih karena produk fesyen merupakan kebutuhan semua orang dan potensi terbesar di Indonesia saat ini adalah wanita, pengguna Internet dan anakanak, sehingga pendekatan secara personal penting untuk melakukan penjualan. Hal yang perlu diperhatikan dalam promosi adalah efektifitasnya, sehingga harus sesuai dana yang dikeluarkan dan timbal balik yang didapat. Cara promosi yang paling efektif untuk produk 
fesyen daring adalah endorse pada artis instagram, memberikan giveaway, ataupun ikut shoutout, sedangkan untuk offline dengan menitipkan pada toko. Daring lebih menguntungkan karena hampir semua pembelian melalui daring.

Strategi promosi menurut Informan-9 adalah melakukan komunikasi yang biasanya dilakukan satu arah, namun saat ini komunikasi dilakukan dua arah dan lebih efektif karena bisa berkomunikasi langsung dengan calon pembeli. Strategi promosi yang tepat untuk fesyen adalah memperhatikan model, karena dalam bisnis daring konsumen bisa beralih ke merek lain dalam hitungan detik. Selain itu bisa menggunakan orang yang berpengaruh dengan endorse ke blogger, sehingga bisa mengenalkan merek. Harus mengetahui sasaran pasar dan positioning produk, karena jika sasaran tidak tepat produk bisa tidak diterima pasar. Persediaan adalah hal yang perlu diperhatikan dalam promosi, seperti yang diungkapakan Informan-9 sebagai berikut:

$\begin{array}{rr}\text { "jangan sampai sudah } \\ \text { melalui } & \text { blogger, }\end{array}$

endorse,stock-nya tidak

$a d a$ " (Informan-9)

Selain itu bisa memengaruhi konsumen dengan menjadi trendsetter. Cara promosi yang paling efektif secara offline dengan masuk komunitas kalangan atas, atau membuat acara pertunjukan peragaan busana, dan harus memiliki toko, sedangkan untuk daring menggunakan endorse dan mencari pemengaruh, serta harus mempunyai web untuk memberi informasi model terbaru, penggunaan media sosial juga bisa seperti line, instagram, dan twitter. Cara tersebut digunakan karena anak muda sekarang sudah beralih ke web sehingga bisa lebih kekinian.

Berdasarkan ketiga ahli yang telah diwawancara, dapat disimpulkan bahwa strategi promosi yang tepat yaitu menggunakan media online dan offline, karena tidak bisa hanya menggunakan salah satunya. Media yang digunakan untuk daring adalah media sosial seperti instagram dan website, sedangkan untuk offline mengikuti pameran peragaan busana. Hal yang perlu diperhatikan dalam promosi adalah efektifitas, pengetahuan produk, persediaan 
barang, dan kecenderungan pasar. Cara promosi yang dilakukan adalah menggunakan gambar yang menarik, tidak banyak kata-kata, endorse, memberi giveaway, ikut shoutout, masuk kalangan elite, dan memberikan sales promotion, seperti diskon.

\section{PEMBAHASAN}

Berdasarkan hasil wawancara dan observasi maka temuan peneliti menunjukkan bahwa pesaing pasti memilih media sosial, seperti instagram dan facebook, website, dan pameran untuk promosinya. Promosi tersebut dilakukan karena dengan media sosial dan website lebih murah dan mudah dijangkau calon pembeli, serta memiliki dampak terbesar, melalui pameran karena dapat mengenalkan merek ke masyarakat yang belum mengenal. Pesaing selalu memperbaharui model pakaian yang terbaru sesuai dengan kecenderungan pasar, sehingga bisa bersaing dan memenuhi keinginan konsumen. Pasar sasaran pesaing adalah fashionista wanita remaja sampai dewasa menengah ke atas. Cara promosi yang dilakukan dengan endorse, serta memberi promosi penjuakan berupa pengumpulan poin.

Konsumen lebih menyukai media sosial, instagram sebagai media promosi, selain itu dengan brosur, broadcast message, dan website. Para konsumen menyukai instagram karena masyarakat saat ini setiap hari melihat instagram dan sering update. Saat ini instagram sedang marak, untuk brosur karena bisa dibagikan ke calon konsumen langsung, untuk broadcast message karena bisa langsung diterima calon konsumen, dan untuk website karena lebih praktis dan bisa diakses dimana-mana. Cara promosi yang lebih disukai konsumen adalah memberikan diskon dan menonjolkan foto yang menarik.

Media yang harus digunakan adalah media daring dan konvensional, karena tidak bisa hanya menggunakan salah satunya. Media daring menggunakan instagram, indonetwork, dan website, sedangkan untuk konvensional menggunakan pameran, peragaan busana, kerjasama dengan butik, dan membuka toko.Alasan menggunakan pameran dan peragaan busana karena sudah ada banyak perancang dan 
produsen ternama yang terkenal mengikuti acara tersebut, sehingga akan banyak pembeli yang datang dan bisa mengenalkan merek, selain itu karena produk fesyen merupakan kebutuhan pokok, memerlukan pendekatan secara personal terhadap konsumen. Kerjasama dengan butik dan membuka toko dilakukan. Penggunaan indonetwork dan website didorong oleh karena setiap bisnis pasti ingin berkembang, dan dengan dua media ini bisa mengembangkan bisnis secara internasional dan antar bisnis, sedangkan untuk instagram, karena sebagai pebisnis harus mengikuti media yang sedang banyak digunakan target pasar. Selain itu menurut para ahli hal yang perlu diperhatikan dalam promosi adalah pengetahuan produk, efektifitas, target dan kecenderungan pasar, karena penjual harus memahami produk yang dijual, harus mempertimbangkan biaya promosi yang dikeluarkan dan timbal balik yang didapat, dan sasaran juga sangat penting, karena jika salah promosi tidak akan sampai ke sasaran yang dituju, selain itu harus mengikuti kencenderungan pasar agar bisa memenuhi keinginan konsumen. Untuk cara promosi, menggunakan gambar yang menarik dan tidak banyak kata-kata, endorse di instagram, memberikan giveaway, ikut shoutout, masuk kalangan atas, dan memberikan promosi penjualan, seperti diskon.

Dari analisis sebelumnya maka media daring yang akan digunakan adalah instagram, dan website. Untuk media konvensional akan menggunakan pameran atau peragaan busana. Cara promosi yang akan dilakukan adalah dengan menggunakan foto yang berkualitas baik, endorse dan pemberian diskon, dan hal yang perlu diperhatikan adalah sasaran konsumennya, agar tidak salah promosi, serta kecenderungan pasar saat ini, sehingga bisa menyesuaikan dengan keinginan pasar.

Selain berdasarkan data yang didapatkan dari narasumber, perancangan strategi ini juga mencakup hasil dari penelitian terdahulu dan dasar teori yang digunakan untuk penelitian ini. Penelitian terdahulu yang dilakukan oleh Listyorini (2013) menyatakan sistem penjualan secara daring dapat 
digunakan untuk promosi, hal ini dikaitkan dengan pernyataan dari narasumber pesaing dan konsumen yang menyatakan media daring lebih efektif dalam melakukan promosi. Penelitian kedua dilakukan oleh Paramita et al. (2014) menunjukkan bahwa promosi dapat meningkatkan penjualan dan memperluas jangkauan konsumen, hal ini dikaitkan dengan pernyataan para ahli yang menyatakan promosi dilakukan untuk calon konsumen melakukan pembelian. Penelitian selanjutnya dilakukan oleh Wei \& Pei-Shan. (2013) menyatakan bahwa endorse meningkatkan perhatian, keinginan dan tindakan konsumen untuk membeli produk. Hal ini dikaitkan dengan data yang didapat dari narasumber pesaing dan para ahli yang menyatakan cara endorse merupakan cara yang efektif untuk promosi.

\section{Konsumen} sasaran RawrClothing adalah remaja wanita usia 18-25 tahun yang menengah keatas dan sosialita, karena dalam promosi perlu mengetahui sasaran pasarnya, sehingga tidak salah menggunakan media promosi. Strategi promosi yang akan digunakan adalah menggunakan instagram, karena berdasarkan analisis data yang dilakukan hampir semua narasumber mengatakan instagram sangat berpengaruh. Selain itu instagram saat ini sedang marak dan hampir semua remaja wanita yang mengikuti perkembangan fesyen memiliki akun instagram, sehingga dengan menggunakan instagram bisa lebih cepat mengenalkan merek dan produk RawrClothing.

Promosi melalui instagram ini dilakukan dengan cara endorse produk ke blogger dan artis. Endorse dipilih karena berdasarkan data yang didapat dari pesaing dan para ahli endorse merupakan strategi yang sangat berpengaruh terhadap peningkatan penjualan. Selain itu endorse ke blogger dan artis saat ini sedang booming karena masyarakat lebih melihat promosi dengan cara endorse. Blogger atau artis yang akan diendorse akan diseleksi dengan cara memilih endorser yang jarang menerima endorse namun tetap memiliki follower banyak.

Selanjutnya melakukan sesi pemotretan dengan model yang menarik dan fotografer yang handal. 
Model menarik yang dimaksud adalah model yang terlihat bagus di foto saat memakai produk Rawr Clothing dan fotografer yang handal adalah fotografer yang sudah sering melakukan sesi pemotretan produk. Hal ini dilakukan karena berdasarkan informasi yang didapat dari konsumen, para konsumen lebih tertarik dengan produk yang memiliki foto yang menarik, karena melalui media sosial calon pembeli tidak dapat melihat produknya secara langsung, sehingga dengan foto yang menarik akan menarik minat beli calon pembeli. Selain itu, untuk rencana kedepan Rawr Clothing juga akan memberikan promosi berupa diskon, karena diskon juga merupakan promosi yang paling digemari konsumen.

Strategi selanjutnya adalah membuat website, sehingga bisa menjangkau pasar lebih luas dan dipercaya prospek konsumen. Namun, pembuatan website akan dilakukan setelah RawrClothing mendapat keuntungan lebih banyak, karena keterbatasan biaya yang dimiliki. Pembuatan website dilakukan karena berdasarkan data yang didapat dari pesaing dan para ahli mengatakan website juga berguna sebagai sarana promosi, selain itu dengan website pebisnis bisa melakukan penjualan sampai ke luar negeri. Website yang dibuat akan eksklusif, sehingga pasar sasaran yang dituju sesuai. Website eksklusif yang dimaksud adalah website dengan kesan minimalis namun menggunakan desain yang berkelas, seperti menggunakan warna burgundy, hitam, putih, atau coklat.

Strategi promosi terakhir yang akan dilakukan adalah dengan mengikuti pameran fesyen berkelas. Pameran berkelas yang dimaksudkan yaitu pameran fesyen yang diikuti oleh lini busana yang eksklusif, seperti Poise24, La Fleur Sign, Shop at Velvet, dan sebagainya. Rencana ke depan RawrClothing akan membuat peragaan busana dengan RawrClothing sebagai sorotan utamanya. Promosi ini digunakan karena berdasarkan saran para ahli, pameran dan peragaan busana sangat berpengaruh terhadap pengenalan merek dan penjualan produk. Selain itu dengan mengikuti pameran dan membuat acara peragaan busana bisa menarik konsumen baru untuk membeli produk RawrClothing. 
Sebelumnya RawrClothing tidak pernah menggunakan strategi foto, endorse, diskon, dan website, namun para pesaing, konsumen, dan para ahli mengatakan cara ini efektif, sehingga RawrClothing akan menerapkan cara tersebut untuk meningkatkan penjualan. Untuk instagram, Rawr Clothing sudah menggunakan instagram sebelumnya, namun karena jarang memperbaharui informasi, penggunaan instagram RawrClothing menjadi kurang efektif. Setelah mengetahui bahwa instagram sangat berpengaruh, peneliti memutuskan untuk menggunakan instagram secara maksimal dengan cara unggah foto minimal tiga kali seminggu. Terakhir strategi dengan mengikuti pameran fesyen berkelas. Sebelumnya RawrClothing pernah beberapa kali mengikuti pameran, namun hasil yang didapat kurang maksimal karena pameran yang diikuti merupakan pameran bertemakan nasional dan mencakup semua bidang, seperti $\mathrm{F} \& \mathrm{~B}$, games, accesories, dan fesyen. Saat ini RawrClothing akan mengikuti pameran yang khusus untuk fesyen dan yang beranggotakan fesyenfesyen lokal ternama di Indonesia.

\section{PENUTUP}

Pendekatan penelitian yang digunakan dalam penelitian ini mampu untuk menggali lebih dalam bagaimana proses merumuskan strategi promosi. Proses pengumpulan data memerlukan waktu yang cukup lama, namun demikian proses wawancara dapat menggali lebih dalam bagaimana informan memberikan perspektif mereka mengenai strategi promosi. Proses observari menguatkan temuan penelitian ini terutama untuk memastikan bagaimana proses perumusan dilakukan.

Simpulan dari penelitian ini adalah promosi yang akan diterapkan oleh RawrClothing adalah melakukan promosi melalui instagram dengan cara endorse, melakukan sesi pemotretan dengan model yang menarik dan fotografer yang handal, memberikan diskon, membuat website, dan yang terakhir mengikuti pameran fesyen berkelas. Untuk rencana kedepan RawrClothing akan membuat peragaan busana dengan RawrClothing sebagai sorotan 
utamanya. Strategi tersebut efektif untuk dilakukan, karena strategi tersebut efektif saat dilakukan oleh pesaing, disukai oleh konsumen, dan disarankan oleh para ahli.

Keterbatasan penelitian ini terutama terletak pada sulitnya untuk mengadakan pertemuan dengan informan karena kesibukan mereka. Oleh karena itu saran penelitian ini adalah waktu yang ditetapkan dalam penelitian lebih panjang.

\section{DAFTAR PUSTAKA}

Chaffey, D., Chadwick, F. E., Mayer, R., \& Johnston, K. 2009. Internet Marketing (4 ed.). England: Pearson Education.

David, Fred. 2009. Konsep Managemen Strategis. Jakarta: Salemba Empat.

Emzir. 2010. Metodologi Penelitian Kualitatif Analisis Data. Jakarta: Rajagrafindo Persada.

Ghony, M. D., \& Almanshur, F. 2012. Metodologi Penelitian Kualitatif. Jogjakarta: AR-Ruzz Media.

Hult, G. T., Pride, M. W., \& Ferrell, C. O. 2012. Marketing (16th ed.). United

States: South-Western Cengage Learning.

Ireland et al. 2013. The Management of Strategy: Concept and Cases (10th ed.) International edition. Canada: Cengange Learning.

Kotler, P.,\& Keller, L. 2009. Marketing Management (13th ed.). NewJersey: Pearson Prentice Hall.

Kotler, P., \& Keller, L. 2012. Marketing Management (14th ed.). New Jersey: Pearson Prentice Hall.

Listyorini, Tri. 2013. Analisis Sistem Penjualan Daring pada Perusahaan Garmen di Semarang. Simetris, Universitas Muria Kudus, Vol 1, No. 1., pp. 1-6.

Nazir, S., Tayyab, A., Sajid, A., Haroon ur Rashid, H. U., \& Javed, I. 2012. How Daring Shopping Is Affecting Consumers Buying Behavior in Pakistan?.IJCSIInternational Journal of Computer Science Issues, Vol 9, Issue 3, No. 1., pp. 486-495. 
Paramita, D., Damayanti, M. N.,\&Cahyadi, J. 2014. Perancangan Promosi Etno Fashion Clothing Line Sieto.Jurnal DKV Adiwarna, Universitas Kristen Petra, Vol 1, No. 4., pp. 1-12.

Perreault Jr. W. D., Cannon, J. P., \& McCarthy, E. J. 2009. Essentials of Marketing (12th ed.). Columbus: McGraw-Hill Education.

Putra, Nusa. 2012. Metode Penelitian Kualitatif Pendidikan. Jakarta: RajaGrafindo Persada.

Smith, P.R. 2011.The SOSTAC Guide to Writing The Perfect Marketing Plan (1st ed.) www.PRSmith.org

Sugiyono. 2012.Memahami Penelitian Kualitatif. Bandung: Alfabeta.

Tjiptono, F., \& Chandra, G.2012. Pemasaran Strategik (2nd ed.) Yogyakarta: Andi.

Wei, Pei-Shan., \& Lu, Hsi-Peng. 2013. An examination of the celebrity endorsements and daring customer reviews influence female consumers' shopping behavior. Computers in Human Behaviour, Vol 29., pp. 193-201. 